\begin{tabular}{|c|c|c|c|c|c|}
\hline MUNIBE Antropologia-Arkeologia & $n^{\circ} 67$ & $185-197$ & DONOSTIA & 2016 & ISSN 1132-2217 • elSSN 2172-4555 \\
\hline
\end{tabular}

\title{
Preliminary study of food residues and cooking practices in the Medieval Hospital of Santa Maria della Scala in Siena (Central Italy)
}

\section{Residuos de alimentos y prácticas culinarias en el Hospital Medieval del Santa Maria della Scala en Siena (Italia Central). Resultados preliminares}

PALABRAS CLAVES: Medioevo, hospital, uso de la cerámica, residuos orgánicos, alimentación, Siena-Italy.

GAKO-HITZAK: Erdi Aroa, ospitalea, zeramikaren erabilera, hondakin organikoak, elikadura, Siena-Italy.

KEY WORDS: Middle Ages, hospital, ceramic use, organic residues, food practices, Siena-Italy.

\section{Alessandra PECCI ${ }^{(1)}$ \& Francesca GRASSI ${ }^{(2)}$}

\section{RESUMEN}

El artículo trata sobre el estudio del uso de algunas cerámicas medievales y de los alimentos preparados y consumidos en el Hospital medieval del Santa Maria della Scala en Siena (Italia Central).

Esta investigación muestra la integración entre los datos obtenidos con el análisis arqueológico y arqueométrico (utilizando el análisis de residuos orgánicos) de las cerámicas y la investigación sobre los documentos históricos encontrados en el mismo contexto, el hospital medieval del Santa Maria della Scala en Siena.

Después del estudio arqueológico-formal, algunas cerámicas han sido seleccionadas para el análisis con cromatografía de gases acoplada a espectrometría de masas con el fin de identificar los residuos orgánicos preservados y conocer su contenido original. Los datos obtenidos han sido integrados con la información proporcionada por los documentos escritos encontrados durante el estudio del Hospital acerca de las compras y de la vida cotidiana en su interior.

\section{LABURPENA}

Erdi Aroko zeramika batzuen eta Sienako (Italia erdialdea) Santa Maria della Scala Erdi Aroko Ospitalean kontsumitutako eta prestatutako elikagaien azterketari buruzkoa da artikulua.

Zeramiken azterketa arkeologikoarekin eta arkeometrikoarekin lortutako datuen eta testuinguru berean, Sienako Santa Maria della Scala Erdi Aroko ospitalean, topatutako dokumentu historikoei buruzko azterketaren arteko integrazioa erakusten du ikerketa honek.

Azterketa arkeologiko-formalaren ondoren, zeramika batzuk hautatu dira masen espektrometriari lotutako gasen kromatografiarekin aztertzeko, hala, gordetako hondakin organikoak identifikatzeko eta haien jatorrizko edukia ezagutzeko. Lortutako datuak Ospitala aztertzean topatutako dokumentu idatziek emandako informazioarekin integratu dira. Dokumentuak ospitaleko eguneroko bizitzaren eta erosketen inguruko informazioa dute.

\section{ABSTRACT}

This paper shows the application of an integrated approach to the study of the use of ceramic wares and of the food prepared and consumed in the Medieval Hospital of Santa Maria della Scala in Siena (Central Italy). This approach takes into account data obtained by the archaeological and archaeometrical study of ceramic vessels and the investigation of historical documents recovered at the Hospital.

A selection of ceramic vessels was analysed to identify the organic residues preserved in them and therefore their original content. The analyses were carried out performing different extractions and the samples were analysed with gas chromatography-mass spectrometry. The data obtained were integrated with the information provided in the written documents found during the study of the Hospital, regarding purchases and daily life at the Hospital.

\section{1.- INTRODUCTION}

The study of food practices during the Middle Ages has been traditionally carried out thank to the possibility of studying historical sources (i.e. Montanari for Italy, Flandrin for France). However, during the last decades,

data emerging from the study of archaeological materials have been acquiring importance. Information on dietary practices and land management have been gathered from the study of animal and plant remains recovered in both urban and rural contexts (among others,

\footnotetext{
(1) Alessandra Pecci, ERAAUB, Universitat de Barcelona, C/Montalegre 6-8, 08001 Barcelona (Spain); Dipartimento di Biologia, Ecologia e Scienze della Terra, Università della Calabria, Via P. Bucci, cubo 12B, Arcavacata di Rende, Cosenza (Italy), alepecci@gmail.com (2) Francesca Grassi, Marie Curie Fellow, Dpto. de Geografía, Prehistoria y Arqueología, c/Francisco Tomás y Valiente s/n, 01006 Vitoria, Universidad del País Vasco-Euskal Herriko Unibertsitatea, (Spain) fragrass20@gmail.com
} 
ALBARELLA 1999; BANDINI MAZZANTI et al. 2009: BUONINCONTRI et al. 2007; CORBINO and MAZZA 2013; GRAU-SOLOGESTOA et al. 2016; VAN DER VEEN et al. 2013; VIGIL-ESCALERA GUIRADO et al. 2013; WOOLGAR et al. 2006). Furthermore, investigation of anthropological remains from cemetery communities, along with isotopic analyses of bones have provided important data on paleodemography, paleopathology and, more rarely, paleonutrition (HAKENBECK et al. 2010; HERRSCHER et al. 2001; FORNACIARI, 1984; FORNACIARI et al. 1984; FULLER et al 2010; JOHANSEN et al. 1986; KOSIBA et al. 2007; MALLEGNI 1987; MALLEGNI, FORNACIARI 1985; MAYS 1997; MULDNER, RICHARDS 2007; MULDNER G.H. 2009; MUNDEE 2009; POLET and KATZENBERG 2003; RETISEMA et al. 2010; YODER 2010). Some of these studies have explored the basis of nutrition in the Middle Ages and other complex topics, including food and social issues, such as gender, identity and cultural changes. An important role in the understanding of food production and preparation is played by the study of ceramic vessels (among others, BIDON 2005; CANTINI 2005, CANTINI et al. 2015; DE GASPERI et al. 2006; DE FERRARI 1996; DE VINGO 2011; GABRIELI 2015; GRASSI 2010; GELICHI and BALDASSARRI 2010; GIOVANNINI 2001; MELLOR 1994; MOLINARI 2003), which can be integrated by residue analysis of ceramics, allowing to obtain information on the food prepared and consumed in the different vessels (i.e. CHARTERS et al. 1993, 1995; COTTICA and NOTASTEFANO 2006; GIORGl et al., 2010; KIMPE et al. 2004; INSERRA et al. 2015; MOTTRAM et al. 1999; PECCl 2009; PECCI and CAU 2014; PECCl et al., 2016; ROMANUS et al. 2008; SALVINI et al. 2008). An interesting approach to ceramic study is the highlighting of differences in dietary habits, which could be related to social status (BECK BOSSARD 1981; POLET, KATZENBERG, 2003; DEGASPERI, PRUNO, CORBINO, 2006). For what concerns Italy, various historical syntheses on food habits during the Middle Ages have been produced since the Seventies using mainly written sources (FLANDRIN, MONTANARI 1996; LARIOUX 1996; MONTANARI 1979, 1988, 1997, 2012, 2015; REDON 1994). An important moment for the study of food habits in the Italian Middle Ages was the publication of the 1981 issue of the journal "Archeologia Medievale", where the study of medieval diet was discussed integrating the contributions of various historians and archaeologists. This was a first attempt to investigate the relationship between man and his natural environment, as well as between production and consumption of food. As for medieval Tuscany, the contribution of Ginatempo, who used archaeological data for historical interpretation of food practices, was crucial, as she firstly highlighted the potential of combining different sources, involving data obtained from the study of faunal and human remains (GINATEMPO, 1984, 1988). Following this line of research, the study of ceramic vessels recovered in Tuscany and the analysis of organic residues preserved in them have improved our knowledge of ceramic use and food practices during the
Middle Ages. The results have been particularly fruitful especially when integrated with botanical and faunal studies (BUONINCONTRI et al. 2007, in press; CANTINI et al. 2015; GIORGI et al., 2010; GOBBATO, GRASSI, 2000; GRASSI, 2004, 2007, 2010; PECCI, 2004, 2005, 2009, 2015; SALVINI et al. 2008).

Although the application of residues analyses on archaeological materials began in the 1970s (CONDAMIN et al., 1976; CONDAMIN, FORMENTI, 1978), and since then this kind of study has greatly improved (COLOMBINI, MODUGNO, 2009; BARNARD, EERKENS, 2007; EVERSHED, 1993, 2008; GARNIER, 2007; GUASH JANE et al. 2004; KIMPE et al., 2004; PECCI, 2009; NIGRA et al. 2014; REGERT 2011; ROMANUS et al., 2009; SALVINI et al., 2008), to date few investigations of residues in vessels related to health care exist. In this line of research, the majority of vessels analyzed are mostly related to the preparation of medicines (for instance PÉREZ-ARANTEGUI et al. 2011; FRASER et al. 2011). Despite the understated investigation of food residues in ceramic vessels from hospitals, food had a crucial role in the care of the body and the soul during the Middle Ages (HAGEN 2006; MONTANARI 2012; MURRAY JONES 1997; WALLIS 2010). Food restrictions related to religious events (involving mainly the abstention from meat and consumption of other animal products) as well as food consumption recommendations related to specific body characteristics, as suggested i.e. in the famous Tacuina Sanitatis, were, in fact, important elements of medieval daily life.

In this contribution, we present an integrated approach to the study of the use of different Medieval ceramic vessels, along with information on the food prepared and consumed at the Hospital Santa Maria della Scala in Siena (Central Italy) (Fig. 1). A selection of ceramic vessels previously studied archaeologically were analysed to identify the organic residues preserved in them. A crucial aspect of the research is that it was possible to relate the data obtained from the residue analyses with those recovered from the written documents found at the Hospital. In fact, during the investigations of the Hospital, Beatrice Sordini (SORDINI 2004 and 2010)

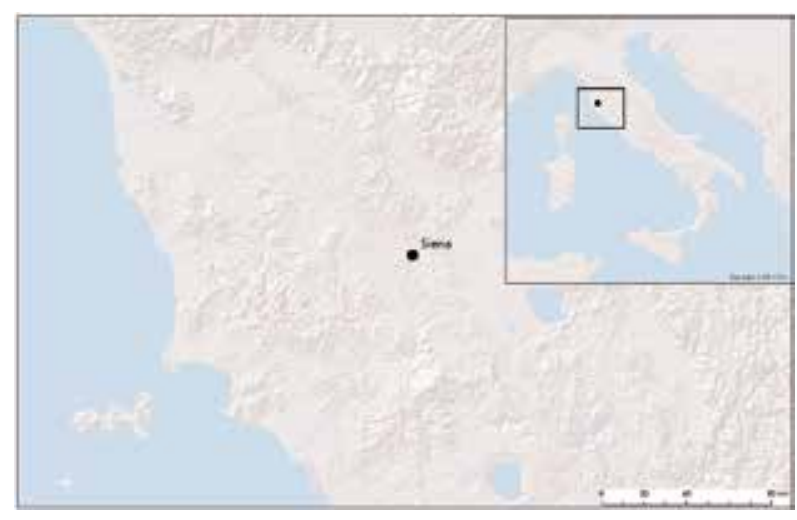

Fig. 1. Location of Siena (Italy) / Localización de Siena (Italy). 
studied a rich collection of documents belonging to the Medieval Inventory of the facility. These documents consisted of expense records (Registro di spesa), which included information related to the life of the Hospital. In particular, they enlighten us on the purchase of food, clothing, animals and other necessities of those who lived and worked at the hospital, as well as of its guests. Additional records include information about the objects and furniture present inside the Hospital.

This integrated approach, despite its great potential of comparing data coming from different sources, can be applied only rarely due to the difficulties of having available at the same time archaeological and archaeometric data (in this case from organic residue analysis), along with information preserved in historical documents recovered from the same context.

\section{2.- THE SANTA MARIA DELLA SCALA HOSPI- TAL AND THE RECOVERY CONTEXT}

The Santa Maria della Scala Hospital was an important institution for care and hospitality during the Middle Age. It was located at the heart of the town of Siena, in front of the cathedral. Many pilgrims spent time there, and many people with illnesses were cared for. Several of those who stopped or died there left their goods as a donation to the hospital, and with time the assets of the institution grew considerably and extended far beyond the town's walls (PICCINNI, TRAVAINI, 2003).

The archaeological excavations carried out in and around the hospital complex, in the framework of the restoration works aimed at creating a site Museum revealed a long occupation of the area, which began during the Etruscan period $\left(7^{\text {th }} \mathrm{C}\right.$. BC) and continued through the centuries until the Middle Ages. Many Medieval phases were identified, mainly associated with the function of hostel and hospital (BOLDRINI, PARENTI, 1991; CANTINI, 2005).

The abundant ceramic vessels found during the excavations have provided information on the broad spectrum of ceramic assemblages used during the $14^{\text {th }}$ century in the kitchen, on the table and for storage (GRASSI, 2001 and 2004). The vessels studied were recovered during the 1998-2000 excavations conducted by the University of Siena, in the framework of the project for the restoration and conservation of the Santa Maria della Scala Hospital complex (GALLAVOTTI et al., 1987; PICCINNI, 1995). The samples analysed date to the second half of the $14^{\text {th }}$ century AD. They come from Area 18000 of the Santa Maria della Scala Hospital, an outdoor space located close to the city walls. The area was used over the centuries as a place to discard waste from the hospital. Such excavation allowed the understanding of the various occupation phases of the area, providing a chronological sequence for the accumulation of the waste. It also clarified that the area was characterized by the alternation of periods in which retaining walls and sewage systems were built and periods of waste disposal (RADICCHI 2007).
The trash pit where the studied vessels come from was filled in during the $14^{\text {th }}$ century and was located just outside the Hospital. The accumulated materials included building materials, ceramic vessels, glass and animal bones discarded from the Hospital.

A selection of these ceramic vessels was analysed with gas chromatography-mass spectrometry to recover information on the residues preserved in them.

During the $14^{\text {th }}$ century, the hospital had at least two kitchens addressing the separate needs of at least two groups of people: the "sick" and the "healthy" (members of the clergy and secular workers). Different diets were provided to the sick ones depending on their illness (PICCINNI, 1995: 11-23). Moreover, written documents from the Hospital inform that even among the "healthy" population there were differences in the food prepared, i.e. for women, for the Rector of the Hospital, and for the friars (SORDINI, 2004: 39). We are not able, however, to determine whether the vessels investigated came from the waste of the kitchen dedicated to the sick or from the one for the so-called "healthy" people.

\section{3.- MATERIALS AND METHODS}

The residue analysis study focused on nine samples taken from coarse ware cooking vessels found in the waste pit (Table I) (Radicchi 2007). The analyzed vesseIs are two pot-colanders (SMS1, SMS4), two pan/colanders (SMS2 and SMS3), two pans (SMS 9 and SMS10) and three testi (coarse ware plates used for cooking) (SMS5, SMS6 and SMS7)(Table I, Figure 2). All the vessels show soot marks attributed to their use over flame.

All the samples were mechanically cleaned with a scalpel to avoid post-depositional contamination and then ground to obtain a fine powder.

Different extraction were carried out on the samples:

a. The total lipid extract and its hydrolysis was obtained following MOTTRAM, et al. (1999). $10 \mu$ of a standard solution of octacosane $(1 \mathrm{mg} / \mathrm{mL})$ were added to the powder before extraction.

\begin{tabular}{|l|l|l|l|l|l|}
\hline Sample & SU & Project $\mathbf{n}$. & Form & $\begin{array}{l}\text { Number } \\
\text { in Fig. } \mathbf{~}\end{array}$ & Part sampled \\
\hline SMS1 & 18407 & 2 & Pot-Colander & 1,2 & Bottom \\
\hline SMS2 & 18047 & 6 & Pan-colander & 3 & Bottom \\
\hline SMS3 & 18047 & 8 & Pan-colander & 3 & Bottom \\
\hline SMS4 & 18306 & 1320 & Pot-Colander & 1,2 & Bottom \\
\hline SMS5 & 18306 & 1321 & Testo & 4 & Bottom \\
\hline SMS6 & 18407 & 16 & Testo & 4 & Bottom \\
\hline SMS7 & 18407 & 19 & Testo & 4 & Bottom \\
\hline SMS9 & 18407 & 4 & Pan & 5 & Bottom \\
\hline SMS10 & 18306 & 1322 & Pan & 5 & Bottom \\
\hline
\end{tabular}

Table 1: Samples analysed / Muestras analizadas. 

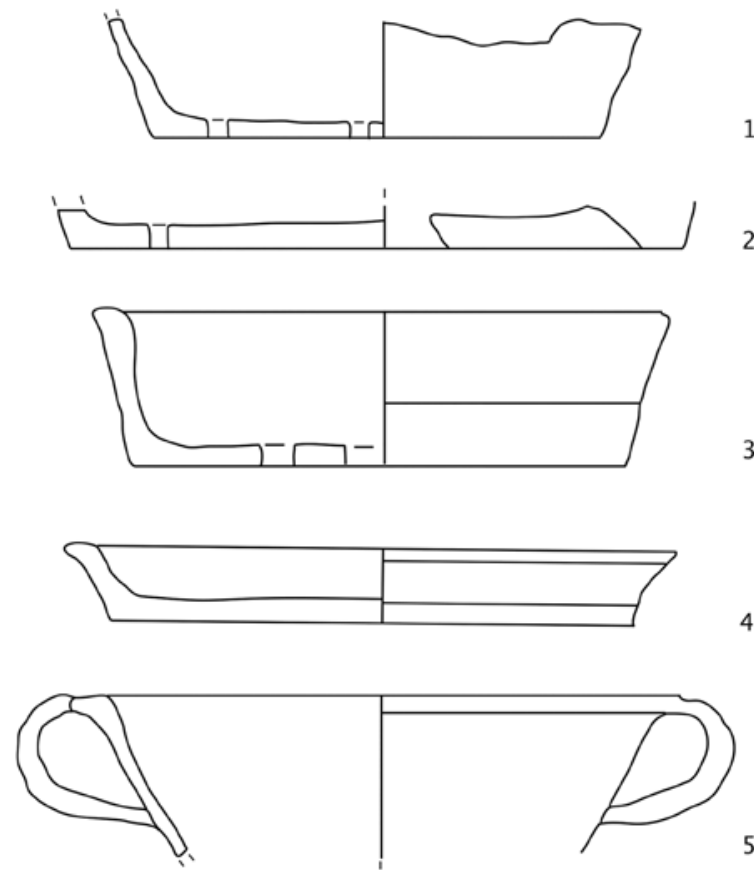

0

$10 \mathrm{~cm}$.

Fig. 2. Ceramics analysed. Holes can be seen in the bottom of vessels 1,2 and 3. 1 and 2: pot colanders; 3: pan colander; 4 testo; 5 pan colander (modified after Radicchi 2007). / Cerámicas analizadas. Los agujeros pueden verse en la parte baja de las vasijas 1, 2 y 3. 1 y 2: escurridores; 3 : colador; 4 tiesto; 5: colador (modificado despues Radicchi 2007).

b. After the total lipid extract a hydrolysis with $\mathrm{KOH}$ in water ( $1 \mathrm{M}, 3 \mathrm{~mL}$ ) was carried out on the solid fraction (GIORGI, et al. 2010).

c. The extraction aimed at identifying wine residues was carried out on 1 gram of powder following PECCl et al. (2013).

All the extracts were derivatised by adding $25 \mu \mathrm{L}$ of N,O-bis (trimethylsilyl) trifluoroacetamide (BSTFA, Sigma-Aldrich) and heating at $70^{\circ} \mathrm{C}$ for $1 \mathrm{~h}$.

The samples were analysed by GC-MS using a gas chromatograph CP3800 (Varian, Walnut Creek, CA, USA) equipped with a DB5 $30 \mathrm{~m}, 0.25 \mathrm{~mm}$ (i.d.) - 0.25 $\mu \mathrm{m}$ film thickness fused silica capillary column, and a mass spectrometer Saturn 2000 (Varian, Walnut Creek, CA, USA) operated in the electron ionization mode (70 $\mathrm{eV})$. The mass range was scanned in the range of $\mathrm{m} / \mathrm{z}$ 40-650. The $\mathrm{GC}$ oven temperature was held at $50^{\circ} \mathrm{C}$ for $1 \mathrm{~min}$, then it was raised at $5^{\circ} \mathrm{C} / \mathrm{min}$ up to $300^{\circ} \mathrm{C}$ and held isothermally for $10 \mathrm{~min}$.

\section{4.- RESULTS OF THE ANALYSES}

\subsection{The Pans}

The presence of cholesterol, which is accompanied by high stearic acid, and monostearin in both pan samples (SMS 9 and SMS 10) indicates the cooking of abundant animal products in the pans (Figure 3). In both samples there are also odd number fatty acids $\left(\mathrm{C}_{15}\right.$ and $\left.\mathrm{C}_{17}\right)$ in branched forms. Although no isotopic analyses were carried out, their presence suggests that at least part of the animal products cooked came from ruminants (MOTTRAM et al. 1999; EVERSHED, 2008; REGERT, 2011).

Both pans show evidence of vegetal products: B-sitosterol is present and the $\mathrm{C}_{9}$ acid is the highest among the short chain fatty acids. Azelaic acid is the highest amongst the dicarboxilic acids in the chromatogram of extraction (c) of sample SMS 10, being typical distributions resulting from the cooking of oil. (PECCI, 2005; PECCl et al. 2015).

Dehydroabietic acid is present in both samples. This acid is a marker of Pinaceae products that could be related to an organic coating of the vessels or a content. In fact, Pinaceae products are common in Tuscan unglazed Medieval vessels and their identification has led to the suggestion of regular use of this organic material as a coating of ceramic vessels (PECCI, 2006; PECCI, 2009). However, Pinaceae products were also used for medical purposes. Mattioli, a $16^{\text {th }} \mathrm{C}$. doctor and writer from Siena, taking inspiration from Dioscorides, says they had different medical uses, through ingestion and as ointment (MATTIOLI 1549). Moreover, Sordini has identified products used in the Hospital of Santa Maria della Scala that could be related to resins and pitch (SORDINI, 2004: 36, see paragraph 6). Therefore, these products could also be related to the content of the vessels.

\subsection{The testi}

Testi are cooking plates typical of Medieval Italy (PRUNO 2003, VANNINI, PRUNO 2015). Samples SMS5, SMS6, and SMS7 belong to this vessel type. They all show internal and external soot marks.

In sample SMS7, the residues are scarce and there is much contamination from plastic (phthalic acids). However, amongst the residues identified, cholesterol (marker of animal products), is abundant, and $\mathrm{C}_{15}$ and $\mathrm{C}_{17}$ in branched forms, markers of ruminants products, are also present. Moreover, the traces of B-sitosterol, $\mathrm{C}_{18: 1}$ acid more abundant than $\mathrm{C}_{18: 0}$ and acid $\mathrm{C}_{9}$ being the highest acid in the chromatogram, suggest that both animal and vegetable origin lipids are present in the sample. In SMS 6 too, residues are scarce. However, there is cholesterol, $\mathrm{C}_{15}$ and $\mathrm{C}_{17}$ in branched for$\mathrm{ms}$ both in the total lipid extract and in the hydrolysis, suggesting the cooking of animal products (Figure 4). In the sample, vegetable products are indicated by the 

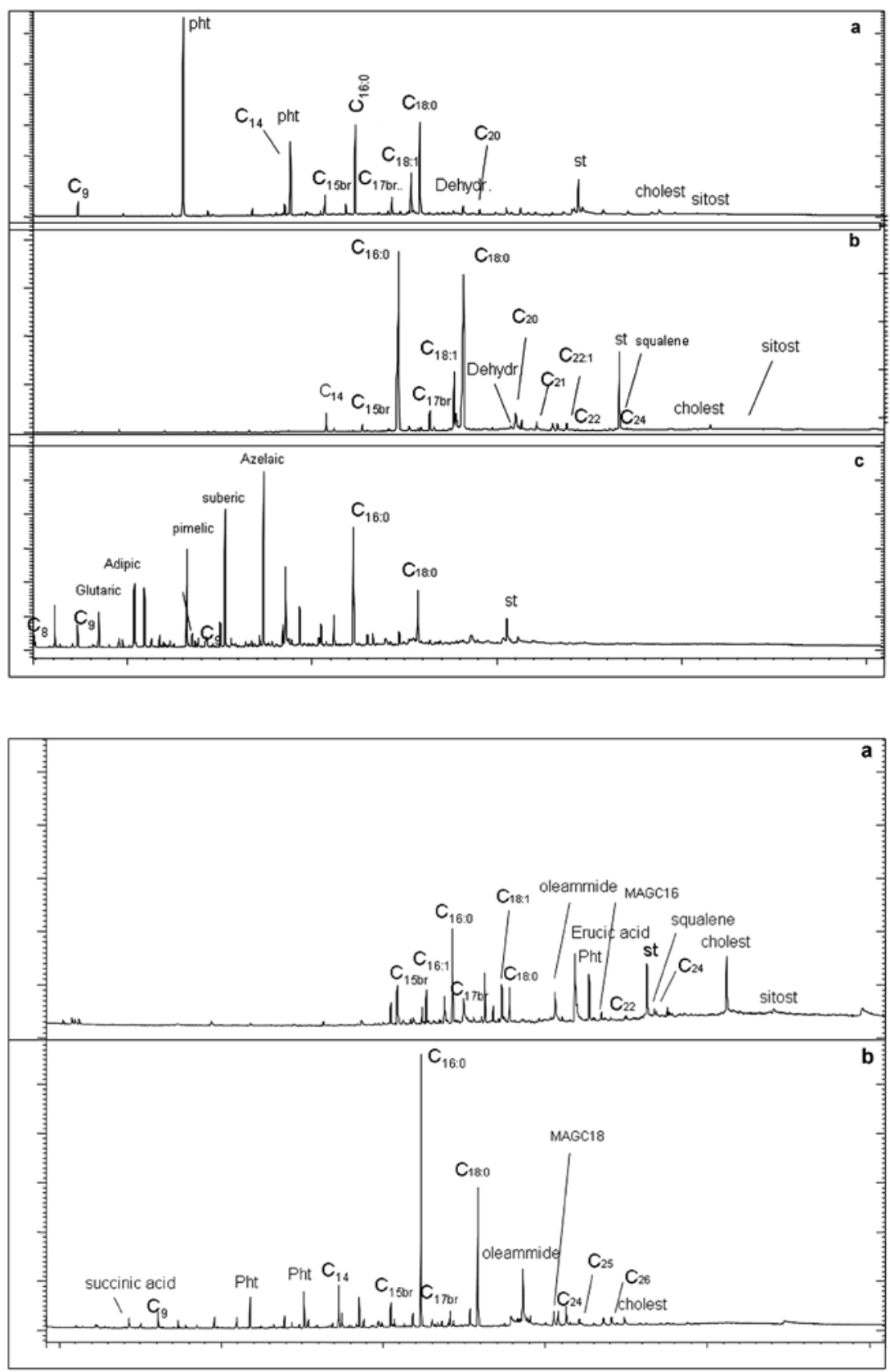

Fig. 3. Chromatograms obtained with the analysis of the total lipid extract (a) and the extract for the identification of wine markers (b) of sample 10 and the total lipid extract of sample 9 (c) / Cromatogramas obtenidos con el análisis del extracto lipídico total y el extracto para la identificación de marcadores de vino de la muestra 10 y del extracto total de lipido de la muestra 9 traces of B-sitosterol. Moreover, $\mathrm{C}_{18: 1}$ is similar to $\mathrm{C}_{18: 0}$ in the total lipid extract, while in the hydrolysis on the solid fraction there is abundant oleamide, which could derive from contamination or from a degradation of the $\mathrm{C}_{18: 1}$ (VACCARO et al., 2013). In the hydrolysis of SMS 5 azelaic acid is the highest amongst dicarboxylic acids, suggesting (together with $\beta$-sitosterol) the presence of a vegetable oil, possibly olive.

The dehydroabietic acid in the samples of the three testi indicates that Pinaceae products are present in all of them.

\subsection{The colanders}

SMS1 and SMS4 are pot-colanders, while SMS2 and SMS3 are pan-colanders. These forms are characterized by the presence of holes in the bottom, pot-colander being deep vessels, while pan-colanders shallow.

\subsubsection{The pot - colanders}

In colander SMS1 the residues are not very abundant. However, cholesterol and the high proportion of stearic acid suggest the presence of animal origin pro- 
ducts (Figure 5). Furthermore, the ß-sitosterol indicates the contact with vegetal products. The presence of long chain alcohols $\left(\mathrm{C}_{24}-\mathrm{C}_{32}\right.$ ), fatty acids (until $\mathrm{C}_{30}$ ), and hydrocarbons may be related to the presence of waxes, which might derive from postdepositional contamination or from the leaves of vegetables that were filtered in the colander. (EVERSHED, 2008).

SMS4 has thin walls and only four small holes on the bottom (approx. $2 \mathrm{~mm}$ wide), which were made before the firing of the vessel (RADICCHI, 2007). The sample shows abundant animal products that are comparable to those of the pans and are indicated by the presence of cholesterol, abundant $\mathrm{C}_{18: 0}$, (Figure 6). Traces of $\mathrm{C}_{15}$ and $\mathrm{C}_{17}$ in branched forms suggest that these products come, at least in part, from ruminants. The presence of short chain fatty acids (included $\mathrm{C}_{6}$ and $\mathrm{C}_{8}$ ) could be associated with dairy products, but to confirm it, isotopic analyses should be carried out. In the hydrolysis of sample SMS4, B-sitosterol is present, suggesting that the vessel probably also came into contact with vegetal origin substances. $\mathrm{C}_{9}$ is the highest amongst short chain fatty acids, and there is abundant oleammide.

Finally, in both SMS4 and SMS1 samples there are traces of dehydroabietic acid, marker of Pinaceae products.
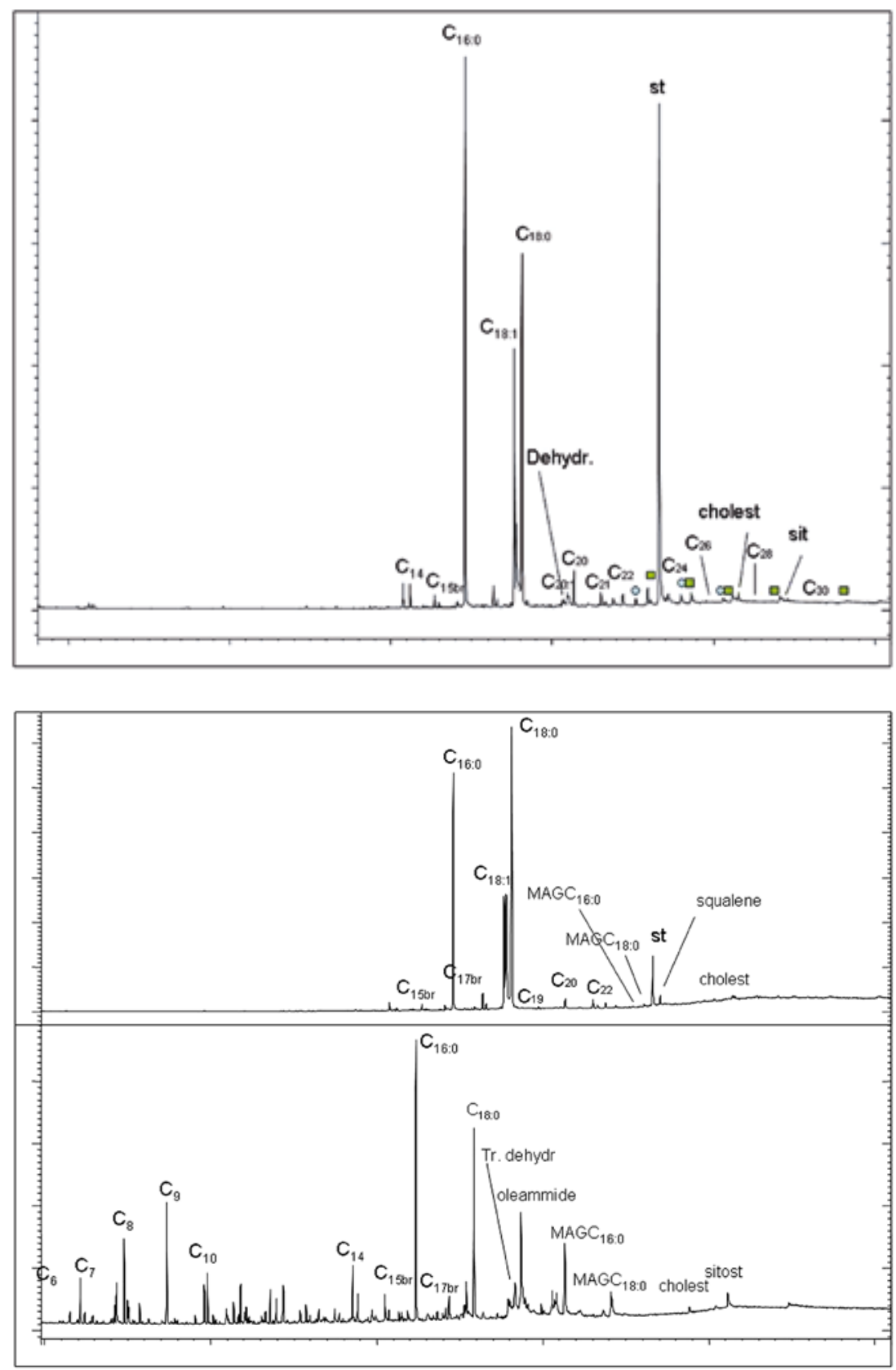

Fig. 5. Chromatogram obtained with the analysis of sample 1 / Cromatograma obtenido del análisis de la muestra 1.
Fig. 6. Chromatograms obtained with the analysis of the total lipid extract (a) and its hydrolysis (b) of sample 4 / Cromatogramas obtenidos del analisis del extracto lipídico total y su hidrólisis de la muestra 4. 


\subsubsection{The pan-colanders}

SMS2 and SMS3 are pan-colanders, and are very similar to a pan-colander coming from the Carmine Convent in Siena that was previously analysed, mainly because of the dimension of the holes (GIORGI et al. 2008; PECCl et al., 2006).

While the pan-colander from the Carmine Convent had no residues, SMS2 shows animal origin products, with cholesterol, $\mathrm{C}_{15}$ and $\mathrm{C}_{17}$ in branched forms and short chain fatty acids, (including $\mathrm{C}_{5}$ and $\mathrm{C}_{6}$ ), which suggest the possibility of contact with ruminant fats and dairy products although isotopic analyses should be performed to verify it. The traces of $\beta$-sitosterol, together with traces of $C_{18.2}$ (linoleic acid), and the fact that $C_{9}$ is the highest peak amongst the short chain fatty acids suggest the presence of a plant oil, which - due to the linoleic acid- could be different from olive oil. In SMS 2, dehydroabietic acid, marker of Pinaceae products, is more abundant than in SMS1 and 4.

In sample SMS3 dehydroabietic acid is especially abundant. This could indicate that the colander was heavily coated with Pinaceae products or that it was used to filter these products. Moreover, $\beta$-sitosterol and long chain hydrocarbons, possibly related with some vegetable waxes, have been identified.

\section{5.- DISCUSSION OF THE RESULTS}

The results of the analyses suggest that most of the ceramic vessels were in contact with animal and vegetal products.

In the pans, the animal products identified are probably related both to the cooking of meat and to the use of animal fat and lard as a condiment (MONTANARI 2012). As for the intake of meat, the written documents found at the Santa Maria della Scala state that both the sick and the healthy consumed some meat. Usually the sick ate "white meat", chicken, young goat, and veal, which can be better digested, while the healthy ate mostly lamb, ox, goat, and pig (SORDINI, 2004). The presence of odd numbers fatty acids in branched forms confirms the consumption of ruminant animals, although isotopic analyses should be performed to verify it.

Written documents from the hospital do not speak about cooking practices. However, in the Middle Ages pots were commonly used to boil food, while pans were used for roasting, stewing, and frying (GRASSI, 2010: 16). Sometimes meat that was previously boiled in pots could be later roasted or fried in pans (DE VINGO, 2011: 82-83; GIOVANNINI, 1994; GRASSI, 2004: 74-76). In fact, during the Middle Ages meat was often very hard, since the animals were often old, therefore long and/or multiple cooking processes were very common (GIOVANNINI, 1994; MONTANARI, 1988). The analyzed pans might then have been used to roast, stew, or fry meat. Because those objects bear soot marks on the bottom, we suppose that pans where used for cooking by direct contact with fire.

As for the condiments employed at the hospital, the documents state that the sick used only oil and vinegar, which are lighter, while the healthy could also eat food garnished with animal fats such as lard (SORDINI, 2004: 29). No traces of vinegar (whose markers are the same of wine with exctraction c, PECCl et al. 2013), were identified in the analyzed vessels. On the contrary, abundant traces of possible vegetable oils are present in the pans and in the testi SMS5 and SMS7. In fact, the distribution pattern of the chemical compounds identified suggests the presence of cooked oils. The traces identified in the pans could therefore be caused by the use of plant oils in the roasting or frying process, in order to prevent the food from sticking, or as a condiments.

Vegetables were also very common in the diet of the sick and the healthy at the hospital. The purchase record shows that during the summer pumpkins, cabbage, and salad were consumed in large quantities. Instead, in spring and in September cabbage, minute (mixed herbs intended for boiling and to be chopped), salad, and leafy greens were bought. In winter, large amounts of turnips, cabbage, leeks, and carrots entered the hospital. In addition, garlic, onion, and parsley were regularly consumed and used for their therapeutic qualities. Many of the vegetables consumed came from the hospital's own garden, which was dedicated to growing vegetables for the domestic needs of the structure. For instance, the registers mention that onions, garlic bulbs and cabbage were bought to be planted in the garden (SORDINI, 2004: 17-19). Many of them could have been consumed both as food and as medicines (WILLIS 2010).

Traces of vegetal waxes were identified in colanders SMS1, SMS2, SMS3. Although their origin should be better investigated, and they could also derive from contamination, it is possible that these waxes are a by-product of the filtering of vegetables leaves previously boiled in pots, such as the leafy vegetables mentioned above, which were consumed throughout the year (SORDINI, 2004). For the moment we can say that no markers of Brassicaceae nor allium porrum are present in the studied vessls. Leafy vegetable were an important ingredient of the Tuscan diet during the Middle Ages and chemical traces of Brassicaceae have been identified in pots recovered at other archaeological sites in Tuscany. (BUONINCONTRI et al., 2007, in press; GIORGI et al., 2010; MAZZI, 1981; SALVINI et al., 2008; PECCI, SALVINI, 2007).

Cheese is often mentioned in the hospital purchase records, suggesting a wide consumption of this product. Together with eggs, cheese was eaten on the days in which the religious calendar called upon the faithful not to eat meat (The vigilie), and it is possible that also the inhabitants and workers of the hospital adhered to these indications (SORDINI 2004: 27). Although isotopic analy- 
ses should be performed to verify it (EVERSHED 2008; REGERT 2011; STYRING et al. 2015), the residues identified in colander SMS4, are related to animal products and could be associated with dairy products. These data seem consistent with the hypothesis that colanders were used to drain cheese, as suggested in many Medieval recipes (DE FERRARI, 1996: 113-115; REDON, 1994). Animal products were also found in the SMS2 sample. However, the holes of this vessel are wider and would not be appropriate for the production of cheese.

It is more difficult to understand the origin of the vegetal fats identified in this colander (SMS4), but it is possible that colanders had multiple uses and that the by-products of these uses accumulated over time producing the different residues identified (DE FERRARI, 1996).

The high amount of Pinaceae products in SMS3 could be related to a thick coating, or, more likely, could suggest its use for filtering resin or pitch. The written documents of the hospital speak about the use of substances such as "ragia di pino" (pine resin) and "pece nera" (black pitch) (SORDINI, 2004: 36) used as ingredients for the therapies of the wealthier, and these probably come from Pinaceae products. Among the medicines bought by the hospital, there was also "ragievo" or "ragiea" probably a kind of resin (SORDINI 2004: 37). As stated above, pitch had long been used as a medicine, since Dioscorides to Mattioli (MATTIOLI 1549). Therefore, there could be a relationship amongst the residues identified and the use of these substances.

Finally, as for the testi, they have been traditionally interpreted as plates for the cooking of bread or focacce (GRASSI, 2011; PRUNO, 2003; QUIROS CASTILLO, 1998; VANNINI, PRUNO, 2015). The internal and external soot marks are consistent with this use. Here there are fewer residues than in the pans. These residues could indicate that at least some fat could have been used to prevent the contents from sticking to the ceramic, and to give flavor to the bread. Oil, lard or milk might have been added in these cases. In this regard, it is very interesting to note a document that records the purchase of eight trays to make "migliacci", traditional Tuscan thin focacce, a sort of thin bread prepared with fat and pig blood. Unfortunately, no analyses aimed at identifying starch residues in the ceramics have been carried out. However, it is possible that the testi found in the hospital (with a rim diameter of about $30 \mathrm{~cm}$ ) might have been suitable for preparing this traditional food (GRASSI 2004: 79).

\section{CONCLUSION}

This study provides a new insight onto the daily life at the Medieval hospital, combining different of sources: written records, archaeological and archaeometrical data.

Although future research should broaden the spectra of the techniques applied, we provided the first pilot study of a Medieval Hospital kitchen complex.
In the future, it will be interesting to complement this investigation, carrying out isotopic analysis of the residues preserved in the vessels. This will provide a deeper understanding of the species of the animal products identified, and confirm whether dairy products and cheese are present in the analysed vessels (EVERSHED 2008; REGERT 2011; STYRING et al. 2015). Furthermore, starch analyses could help in the identification of the traces of legumes and cereals, which cannot be identified by the residue analysis. In order to obtain a deeper insight on the products at disposal and on food habits, the data obtained from the residue analysis of ceramic vessels should also be integrated with those coming from archaeobotanical and archaeozoological studies, as well as paleonutritional studies of the human bodies recovered in the same archaeological context.

The research presented here allowed to make a step forward toward the understanding of the use of pottery and the type of food prepared at the hospital. The residue analysis performed has confirmed the use of pans to cook (roast, stew, or fry) meat and/or other animal products, using for this purpose not only animal origin condiments but also plant oils, possibly deriving from olive tree and other plants. It has also confirmed the introduction of animal and vegetal products in the testi, probably aimed at preventing the bread to stick to the surface. Moreover, it is only through the residue analysis that we know that, at least for the vessels analysed, neither wine nor vinegar were used in the cooking. This confirms what emerged from the analysis of vessels coming from other medieval Tuscan contexts, where wine or its derivatives was identified in pots and jugs, but never in pans, colanders or testi (PECCI 2009, 2015). On the contrary, one medieval pan from Cyprus shows residues of wine or its derivatives possibly related with a sauce or a condiment (PECCl et al. 2016).

It is worth noting that residue analysis highlights the sum of the residues absorbed by the vessels and cannot make a "stratigraphy" of the absorption. This is probably why we observe multiple residues in the colanders that could be related to a multiple use, such as draining cheese, possibly filtering leafy vegetables and preparing Pinaceae products that could be used in the hospital. These last products are common in medieval vessels and could also have been used to coat the vessels (PECCI, 2006).

The exceptional find of written documents at the hospital has given the opportunity of relating the residues identified in the ceramic vessels to the foodstuff described in the Hospital written records. This allowed for specific knowledge of some of the food that the archaeometric analysis identified in a more general way (i.e. the animal products). Moreover, these written sources have contributed with integrating data about most of the vegetal products consumed at the hospital that residue analysis could not provide by itself. This research, in conclusion, yielded a broader idea of the diet of the different people living within and around the Medieval 
hospital and, in general, it should be considered a pilot project for similar studies in contexts in which we can compare multiple sources.

\section{ACKNOWLEDGEMENTS}

The ceramics were recovered during the 19982000 excavations carried out by the University of Siena, directed by R. Francovich, A. Molinari, G. Pucci, and D. Manacorda in the framework of the project for the restoration and conservation of the Santa Maria della Scala Hospital. F. Grassi participate dt in this project as a graduate researcher at the University of Trieste (F. Grassi, 2001, La ceramica da dispensa e da cucina dell'Ospedale di Santa Maria della Scala, Siena (XIV-XV secolo", Unpublished Master thesis, University of Trieste), and tutored a BA thesis on ceramics founded in the hospital, discussed by Silvia Radicchi in the University of Siena, (Lo scavo archeologico dell'area 18000 dello Spedale di Santa Maria della Scala: studio dei materiali).

A. Pecci conducted the analyses in the framework of the Project Archeologia dei Paesaggi Medievali (R. Francovich and M. Valenti) in collaboration whit the Dipartimento di Chimica of the University of Siena (20072009). This contribution is part of the activities of the University of Siena, Department of Historical Sciences and Cultural Heritage, the Dipartimento di Biologia, Ecologia e Scienze della Terra, Università della Calabria and the Equip de Recerca Arqueològica i Arqueomètrica de la Universitat de Barcelona (ERAAUB), Consolidated Group (2014 SGR 845), with the support of the Comissionat per a Universitats i Recerca del DIUE de la Generalitat de Catalunya and the Ramón y Cajal contract RYC 2013-13369, financed by the Ministerio de Economía y Competividad.

\section{REFERENCES}

AA.VV

1981 Problemi di storia dell'alimentazione nell'Italia Medievale. Archeologia Medievale VIII, 9-451.

ALBARELLA, U

1999 'The mystery of husbandry': medieval animals and the problem of integrating historical and archaeological evidence. Antiquity 73(282), 867-875

2011 Ethnozooarchaeology and the power of analogy, in $U$. ALBARELLA \& A. TRENTACOSTE A. (Eds.). Ethnozooarchaeology. The present and past of human-animal relationships. 1-3. Oxford. Oxbow Books.

BANDINI MAZZANTI, M., BOSI, G. \& GUARNIERI, C.

2009 The useful plants of the city of Ferrara (Late Medieval/ Renaissance) based on archaeobotanical records from middens and historical/culinary/ethnobotanical documentation, in MOREL, J.P. \& MERCURI, A. M. (Eds.) Plants and Culture: seeds of the cultural heritage of Europe. EDIPUGLIA.
BECK-BOSSARD, C.

1981 L'alimentazione in un villlaggio siciliano del XIV secolo, sulla scorta delle fonti archeologiche. Archeologia Medievale VIII, 311-320.

\section{BIANCHI, G. \& GRASSI, F.}

2013 Sistemi di stoccaggio nelle campagne italiane (secc. VII-XIII): l'evidenza archeologica dal caso di Rocca degli Alberti in Toscana, in VIGIL ESCALERA A., BIANCHI G., QUIROS J.A. (Eds.). Horrea, graneros y silos. Almacenaje y rentas en las aldeas de la Alta Edad Media. 77-103. Bilbao.

\section{BIDON, A.}

2005 Une archéologie du gout. Editions Picard. Paris.

\section{BOLDRINI, E. \& PARENTI R. (Eds.)}

1991 Santa Maria della Scala. Archeologia e edilizia sulla piazza dello Spedale. All'Insegna del Giglio. Firenze.

BUONINCONTRI, M. P., CORBINO, C. A., DI PASQUALE, G., DONNINI, D., MORI SECCI, M., PECCI, A., PIGNATTELLI, S., SALVINI, L. \& TERZANI, M.

2007 Approccio integrato allo studio dell'alimentazione e deII'ambiente a Firenze nel XIII secolo: risultati preliminari, in FRANCOVICH R., CANTINI F., CIANFERONI C., SCAMPOLI E. (Eds.). Firenze prima degli Uffizi. 662681. All'Insegna del Giglio. Firenze.

BUONNCONTRI, M., PECCI, A. , DI PASQUELE, G., RICCI, P. \& LUBRITTO, C.

In press Multiproxy approach to the study of Medieval food habits in Tuscany (central Italy), Archaeological and Anthropological Sciences, DOI 10.1007/s12520-0160428-7

\section{CANTINI, F}

2005 Archeologia urbana a Siena. L'area dell'Ospedale di Santa Maria della Scala prima dell'Ospedale. All'Insegna del Giglio. Firenze.

\section{CANTINI, F., BUONINCONTRI, S. G. \& FATIGHENTI B}

2015 Ceramica e alimentazione nel Medio Valdarno medievale: il caso di San Genesio (San Miniato-PI), in Proceedings of the 10th International Congresson Medieval Pottery in the Mediterranean. 368-377. Silves-Mértola. 22-27 October 2012.

CHARTERS, S., EVERSHED, R.P., GOAD, L.J., LEYDEN, A., BLINKHORN, P.W. \& DENHAM, V.

1993 Quantification and distribution of lipid in archaeological ceramics: implications for sampling potsherds for organic residues analysis and the classification of vessel use. Archaeometry 35(2), 211-223.

CHARTERS, S., EVERSHED, R.P., BLINKHORN, P.W. \& DENHAM, V.

1995 Mixing of fats and waxes in archaeological ceramics. Archaeometry 37(1), 113-127. 


\section{CORBINO, C. \& MAZZA, P.}

2013 Faunal remains at the castle of Al-Wu'Ayra, in Petra, and at the castle of Shawbak (crusaders' period), in FARES AL- HMOUD. Study of the History and Archaeology of Jordan, 11, Department of Antiquities. 159-164. Ammam.

\section{COTTICA, D. \& NOTASTEFANO, F.}

2008-2009 Caratterizzazione chimica dei residui organici in archeologia. II caso del vasellame d'uso quotidiano nella Hierapolis (Turchia) mediobizantina. Rivista di Archeologia 32-33, 117-129.

DE GASPERI, A., PRUNO, E. \& CORBINO, C.

2006 Cucinare a Prato nel Tardo Medioevo. Scelte e abitudini culinarie di una società urbana - prime analisi, in XXXIX Convegno Internazionale della ceramica. La ceramic da fuoco e da dispensa nel Bassomedioevo e nella prima età Moderna (secoli XI-XVI). Savona: 129-140.

\section{DE FERRARI, G}

1996 Le ceramiche medievali del museo per la ricostruzione di una cucina, in LAVAGNA, R. (Ed.) Museo archeologico di Savona al Priamàr. 113-115. Sagep Editrice. Genova.

\section{DE VINGO, P.}

2011 Food preparation and preservation in north-west Italy: a comparative assessment in the study of early medieval eating an cooking utensils in the settlement of Sant'Antonino in western Liguria and the village of Trino Vercellese in the Po valley, in Processing, Storage, Distribution of Food - Food in the Medieval Rural Environment, Ruralia VIII, 7th-12th september 2009, Lorca. 71-89. Brepols.

\section{FLANDRIN, J.L. \& MONTANARI, M. (Eds.)}

1996 Storia dell'alimentazione. Laterza. Roma, Bari.

\section{FORNACIARI, G. \& MALLEGNI G.}

1984 Su un gruppo di inumati della necropoli di Cornus. Aspetti antropologici, paleopatologici e paleonutrizionali, in L'archeologia romana e altomedievale nell'Oristanese. 213-229.

1987 Paleonutritional Studies on Skeletal remains of Ancient Populations from the Mediterranean Area: an attempt to interpretation. Anthropologischer Anzeiger 45, 361 370.

FORNACIARI, G., MENICAGLI TREVISANI E. \& CECCANTI B.

1984 Indagini paleonutrizionali e determinazione del piombo osseo mediante spettroscopia ad assorbimento atomico sui resti scheletrici di epoca tardoromana della "villa dei Gordiani" a Roma. Archivio per l'antropologia e l'etnologia CXIV, 149-176.

FRASER, S.E., INSOLL, T., THOMPSON, A. \& VAN DONGEN, B.E. 2012 Organic geochemical analysis of archaeological medicine pots from Northern Ghana. The multi-functionality of pottery. Journal Archaeological Science 39(7), 2506-2514.

\section{FULLER, B.T., MARQUEZ GRANT, N. \& RICHARDS, M.P}

2010 Investigation of diachronic dietary patterns on the islands of Ibiza and Formentera, Spain: evidence from Carbon and Nitrogen Stable isotope ratio analysis. American Journal of Physical Anthropology 143 (4), 515-522.

\section{GABRIELI, R. S.}

2015 Sspecialisation and development in the handmade pottery industries of Cyprus and the Levant, in medieval and post-medieval ceramics in the eastern Mediterranean - fact and fiction. 131-153. Brepols.

\section{GALLAVOTTI CAVALLERO, D. \& BROGI, A.}

1987 Lo spedale Grande di Siena. Usher. Firenze.

\section{GELICHI, S. \& BALDASSARRI, M. (Eds.)}

2010 Pensare/classificare. Studi e ricerche sulla ceramica medievale per Graziella Berti. All'Insegna del Giglio. Firenze.

\section{GINATEMPO, M.}

1984 Per la storia degli ecosistemi e dell'alimentazione medievali: recenti studi di archeozoologia in Italia. Archeologia Medievale XI, 35-63.

1988 Corpi e uomini tra scienza e storia: studi di osteo-archeologia umana per l'Italia medievale. Archeologia Medievale XV, 7-65.

GIORGI, G., SALVINI, L. \& PECCI, A.

2010 The meals in a building yard during the Middle Ages. Characterization of organic residues in ceramic potsherds. Journal of Archaeological Science 37, 1453-1457.

\section{GIOVANNINI, F.}

2001 Funzioni delle forme ceramiche e modelli alimentari medievali, in DE MINICIS E. (Ed.). Le ceramiche di Roma e del Lazio in età moderna. 14-22. Roma.

\section{GOBBATO S. \& GRASSI F.}

2000 Gli oggetti della vita quotidiana dell'ospedale, in QUIROS CASTILLO J.A. (Ed.). L'ospedale di Tea e l'archeologia delle strade nella valle del Serchio. 190-207. Firenze.

\section{GRASSI, F.}

2001 La ceramica da dispensa e da cucina dell'Ospedale di Santa Maria della Scala, Siena (XIV-XV secolo". Unpublished Master thesis. University of Trieste.

2004 Gli oggetti in ceramica della cucina e della dispensa, in BELLI M., GRASSI F., SORDINI B., La cucina di un ospedale del Trecento. Gli spazi, gli oggetti, il cibo nel Santa Maria della Scala di Siena. 63-85. Pacini Editore. Pisa.

2007 Le ceramiche non rivestite e con rivestimenti vetrosi rinvenute nella volta absidale, in BIANCHI G., BERTI G. (eds), La chiesa di S.Antimo sopra i Canali a Piombino. Ceramiche e architetture per la lettura archeologica di un cantiere medievale. 305-318. All'Insegna del Giglio. Firenze.

2010 La ceramica, l'alimentazione, l'artigianato e le vie di commercio tra VIII e XIV secolo. II caso della Toscana Meridionale. BAR, British Archaeological Reports International Series 2125. Oxford. 
GRAU-SOLOGESTOA, I, ALBARELLA, U. \& QUIROS CASTILLO J.A.

2016 Urban medieval and post-medieval zooarchaeology in the Basque Country: Meat supply and consumption. Quaternary International 399, 1-12.

HAGEN, A

2006 Anglo Saxon food and drink. Anglo Saxon Books. Norfolk.

\section{HAKENBECK, $S$.}

2013 Potentials and limitations of isotope analysis in Early Medieval archaeology, PCA 3. European journal of Post Classical Archaeologies. 95-111.

HAKENBECK, S., McMANUS, E., GEISLER, H., GRUPE G. \& O'CONNELL T.

2010 Diet and mobility in Early Medieval Bavaria: a study of Carbon and Nitrogen stable isotopes. American Journal of Physical Anthropology 243, 235-244.

HERRSCHER, E., BOCHERENS, H., VALENTIN, F. \& COLARDELLE, $R$.

2001 Comportements alimentaires au Moyen Âge à grenoble: application de la biogéochimie isotopique à la nécropole Saint-Laurent (XIII-XV siècles, Isère), France. Life Sciences 324, 479-487.

JOHANSEN, O.S., GULLISKEN, S. \&, NYDAL, R.

$1986{ }^{13} \mathrm{C}$ and diet: analysis of Norwegian human skeletons Radiocarbon 28, 754-761.

KIMPE, K., DRYBOOMS, C., SCHREVENS, E., JACOBS, P.A., DEGEEST, R. \& WAELKENS, M.

2004 Assessing the relationship between form and use of different kinds of pottery from archaeological site Sagalassos (southwest Turkey) with lipid analysis. Journal of Archaeological Science 31, 1503-1510.

KING, A.

1999 Diet in the Roman world: a regional inter-site comparison of the mammal bones. Journal of Roman Archaeology $12,168-202$

KOSIBA, S.B., TYKOT, R.H. \& CARLSSON, D.

2007 Stable isotopes as indicators of change in the food procurement and food preference of Viking Age and Early Christian populations on Gotland (Sweden). Journal of Anthropological Archaeology 26, 394-411.

LARIOUX, B.

1996 I libri di cucina italiani alla fine del medioevo: un nuovo bilancio. Archivio storico italiano CLIV, 33-58.

2005 Une histoire culinaire du Moyen Âge. Champion. Paris.

MAZZI, M.S.

1981 Consumi alimentari e malattie nel medioevo. Archeologia Medievale VIII, 321-336.
MATTIOLI, M.P.A

1549 II Dioscoride dell' eccellente dottor P. A. Matthioli da Siena: co i suoi discorsi, da esso la seconda volta illustrati, e diligentemente ampliati; con la giunta del sesto libro de i remedi di tutti i veleni, da lui nuovamente tradotto, e con dottissimi discorsi per tutto commentato; con la giunta di tutte le figure delle piante. Roffinello. Mantova.

MAYS, S.A

1997 Carbon stable isotope ratios in Medieval and Later Human skeleton from Northern England. Journal of Archaeological Sciences 24, 561-567.

MELLOR, M.

1994 Oxfordshire Pottery: A Synthesis of Middle and Late Saxon, Medieval and Early Post-medieval Pottery in the Oxford Region. Oxfordshire Architectural \& Historical Society.

MOLINARI, A.

2003 La ceramica medievale in Italia ed il suo possibile utilizzo per lo studio della storia economica. Archeologia Medievale 30, 229-245.

MONTANARI, M.

1979 L'alimentazione contadina nell'Altomedioevo. Liguori. Napoli.

1988 Alimentazione e cultura nel Medioevo. Laterza. Roma-Bari.

2012 Gusti del Medioevo. I prodotti, la cucina, la tavola. Laterza. Roma-Bari.

2015 La fame e l'abbondanza. Storia dell'alimentazione in Europa. Laterza. Roma-Bari.

MOTTRAM, H. R., DUDD, S. N., LAWRENCE, G.J., STOTT, A.W. \& EVERSHED, R.

1999 New chromatographic, mass spectrometric and stable isotope approaches to the classification of degraded animal fats preserved in archaeological pottery. Journal of Chromatography 833, 209-221.

\section{MULDNER, G.H. \& RICHARDS M.P.}

2007 Stable isotope evidence for 1500 years of human diet at the city of York, UK. American Journal of Physical Anthropology 133(1), 682-697.

MULDNER, G.H.

2009 Investigating Medieval diet and society by stable isotope analysis of human bone, in GILCHRIST R. \& REY NOLDS A., (Eds.). Reflections: 50 years of medieval Archaeology, 1957-2007. 327-346. Londra.

MUNDEE, $M$.

2009 An isotopic approach to diet in Medieval Spain in BAKER S., ALLEN M., MIDDLE S. \& POOLE K. (Eds.). Food and drink in Archaeology 2. 64-72. University of Nottingham Conference 2009. Nottingham.

\section{MURRAY JONES, P.}

1997 Materia Medica. The British Library, Mediagraf, Noventa Padovana. 


\section{PECCI, A.}

2004 L'analisi funzionale della ceramica attraverso lo studio dei residui organici. Archeologia Medievale XXI, 527533.

2006 Rivestimenti organici nelle ceramiche medievali: un accorgimento tecnologico "invisibile"? Archeologia Medievale XXIII, 517-523.

2009 Analisi funzionali della ceramica e alimentazione medievale. Archeologia Medievale XXXVI, 21-42.

2015 Food practices in Medieval Florence: the organic residue analysis of ceramic vessels, in D'AQUINO V., GUARDUCCI G., NENCETTI S. \& VALENTINI S., Archeologia a Firenze: città e territorio. Atti del workshop. Firenze, 12-13 aprile 2013. BAR International Series, Oxford.

\section{PECCI, A., GRASSI, F., SALVINI, L. \& GIORGI G.}

2006 Cooking activities in Building yard during the Middle Ages. Organic residues in potshards recovered from the Carmine convent in Siena, in Proceedings del 34th International Symposium on Archaeometry (3-7 May 2004). 583-588. Institución Fernando el Católico (C.S.I.C.). Zaragoza.

PECCI, A., GIORGI, G., SALVINI L. \& CAU, M.Á.

2013 Identifying wine markers in ceramics and plasters with gas chromatography - mass spectrometry. Experimental and archaeological materials. Journal of Archaeological Science 40, 109-115.

PECCI, A. \& CAU, M.Á.

2014 Residue Analysis of Late Roman Cooking pots and Amphorae from Sa Mesquida (Mallorca, Balearic Islands), in POULOU-PAPADIMITRIOU N., NODAROU E., KILIKOGLOU V. (Eds.). LRCW4. The Mediterranean: a market without frontiers. 833-841. BAR International Series S2616. Oxford.

PECCI, A., DEGL'INNOCENTI, E., GIORGI, G., CAU, M.Á., CANTINI, F., SOLANES POTRONY, E., ALÓS, C. \& MIRIELLO, D.

2015 Organic residue analysis of experimental, medieval, and post medieval glazed ceramics. Archaeological and Anthropological Sciences, 1-12. doi:10.1007/ sl2520-015-0262-3.

PECCI, A., GABRIELI, R.S., INSERRA, F., CAU, M.Á. \& WAKSMAN, S.Y.

2016 Preliminary results of the organic residue analysis of $13^{\text {th }}$ century cooking wares from a household in Frankish Paphos (Cyprus). STAR. http://dx.doi.org/10.1080/2 0548923.2016.1183960

VIGIL-ESCALERA GUIRADO, A., MORENO-GARCÍA, M., PENAA-CHOCARRO, L., MORALES MUÑIZ, M., LLORENTE RODRÍGUEZ, L., SABATO, D. \& UCCHESU, M.

2013 Productive strategies and consumption patterns in the Early Medievalvillage of Gózquez (Madrid, Spain). Quaternary International 346, 7-19.

\section{PÉREZ-ARANTEGUI, J., RIBECHINI E., COLOMBINI M.P. \& ES-} CUDERO F.

2011 Characterization of an ancient 'chemical' preparation: pigments and drugs in medieval Islamic Spain. Journal of Archaeological Science 38 (12), 3350-3357.
PICCINNI, G.

1995 Linee di storia dell'Ospedale di Santa Maria della Scala e dell'area circostante, in Santa Maria della Scala. DaIl'ospedale al Museo. 11-21. AL.SA.BA. Ed. Siena.

PICCINNI G. \& TRAVAINI L

2003 Il libro del Pellegrino (Siena 1382-1446). Affari, uomini, monete nell'Ospedale di Santa Maria della Scala. Liguori. Siena.

\section{POLET C. \& KATZENBERG M.A.}

2003 Reconstruction of the diet in a medieval monastic community from the coast of Belgium. Journal of Archaeological Sciences 30, 525-533.

PRUNO, E.

2003 La diffusione dei testelli nell'alto-Tirreno tra XI-XIV sec.. III Congresso Nazionale di Archeologia Medievale. 71 77. Salerno.

\section{QUIROS CASTILLO, J.A.}

2013 Los comportamientos alimentarios del campesinado medieval en el País Vasco y su entorno (siglos VIII-XIV). Historia Agraria 59, 13-41.

RADICCHI, S

2007 Lo scavo archeologico dell'area 18000 dello Spedale di Santa Maria della Scala: studio dei materiali. Unpublished BA thesis in Medieval Archaeology. University of Siena.

REDON, O.

1994 A tavola nel Medioevo: con 150 ricette dalla Francia e dall'Italia. Laterza. Roma-Bari.

RETISEMA, L.J., CREWS, D.E. \& POLCYN M.

2010 Preliminary evidence for medieval Polish diet from carbon and nitrogen stable isotopes. Journal of Archaeological Sciences 37, 1413-1423.

SALAMON M., COPPA A., MCCORMICK M., RUBINI M., VARGIU R. \& TUROSS N.

2008 The consilience of historical and isotopic approaches in reconstructing the medieval Mediterranean diet. Journal of Archaeological Sciences 35, 1667-1672.

\section{SALVINI L., PECCI A. \& GIORGI G.}

2008 Cooking activities during the Middle Age: organic residues in ceramic vessels from the Sant'Antimo Church (Piombino-Central Italy). Journal of Mass Spectrometry 43, 108-115.

\section{SORDINI, B.}

2004 II cibo e la cura, in BELLI M., GRASSI F., SORDINI B. La cucina di un ospedale del Trecento. Gli spazi, gli oggetti, il cibo nel Santa Maria della Scala di Siena. 9-62. Pacini Editore. Pisa.

2010 Dentro l'antico ospedale. Santa Maria della Scala, uomini, cose e spazi di vita nella Siena medievale. Protagon. Siena. 
STYRING, A.K., FRASER, R.A., ARBOGAST, R., HALSTEAD, P. ISAAKIDOU, V., PEARSON, J., SCHAFER, M., TRIANTAPHYLLOU, S., VALAMOTI, S.M., WALLACE, M., BOGAARD, A. \& EVERSHED R.

2015 Refining human paleodietary reconstruction using amino acid $\delta \mathrm{N}$ values of plants, animal and humans. Journal of Archaeological Science 53, 504-515.

YODER, C.

2010 Diet in medieval Denmark: a regional and temporal comparison. Journal of Archaeological Science 37(9), 2224-2236.

VACCARO, E., GHISLENI, M., ARNOLDUS-HUYZENDVELD, A., GREY, C., BOWES, K., MACKINNON, M., MERCURI, A. M., PECCl, A., CAU ONTIVEROS, M. Á., RATTIGHERI, E. \& RINALDI, R.

2013 Excavating the Roman Peasant II: Excavations at Case Nuove, Cinigiano (GR). Papers of the British School at Rome («PBSR») 81, 129-179.

VAN DER VEEN, M., HILL, A. \& LIVARDA, A.

2015. The Archaeobotany of Medieval Britain (c ad 4501500): Identifying Research Priorities for the 21st Century. Medieval Archaeology 37(1), 151-182.

VANNINI G. \& PRUNO E.

2015 Problemi di polifunzionalità nella ceramica medievale, in ROMANA STASOLLA F., ANNOSCIA G.M. (a cura di). Le ceramiche di Roma e del Lazio in età medievale e moderna VII. 7-30.

VIGIL ESCALERA GUIRADO, A., BIANCHI, G. \& QUIROS, J.A (Eds.)

2013 Horrea, graneros y silos. Almacenaje y rentas en las aldeas de la Alta Edad Media: Horrea, magazzini e silos. Granaglie e rendite nei villaggi altomedioevali. Bilbao.

WALLIS, F.

2010 Medieval medicine. A reader. University of Toronto Press. Toronto.

WOOLGAR, C.M., SERJEANTSON, D. \& WALDRON T.

2006 Food in Medieval England: Diet and Nutrition. Oxford University Press. Oxford. 